


\title{
Administrative reforms in Eastern Europe: A comparative legal analysis
}

\author{
DOI: https://doi.org/10.46398/cuestpol.3969.50
}

\author{
Stanislav V. Zlyvko * \\ Valerii A. Bortniak ** \\ Kateryna V. Bortniak *** \\ Iryna P. Storozhuk **** \\ Roman Z. Holobutovskyy ${ }^{* * * * *}$
}

\begin{abstract}
The objective of the article was to analyze the legal regulation of the decentralization reform in Eastern Europe and its impact on the unemployment rate. Methodologically, statistical analysis, hypothetical-deductive method and correlation were used. It was found that the first stage of the reform of the New Civil Service in Poland, Ukraine, Romania, the Czech Republic, Slovenia, Latvia, and Bulgaria began in 1990, but can be called an informal preparatory stage. It is determined that the process of implementation of administrative reforms is influenced by a series of factors: historical, economic, geographical. It is concluded that there is no positive correlation between the effectiveness of public administration and the effectiveness of local self-government in all the countries studied. The reform of decentralization has been shown to have a negative impact on employment. In addition, it found that Poland is the most stable country among those studied, with a high level of efficiency of local self-government. La more negative correlation between the efficiency index of local self-government and employment, and the most positive correlation between local and
\end{abstract} unemployment rate.

Keywords: public administration; decentralization; new public administration; employment; unemployment.

* Professor, Department of Administrative, Civil and Commercial Law and Process, Law Faculty,Academy of the State Penitentiary Service. ORCID ID: https://orcid.org/oooo-00o3-2732-3144. Email: zlslsv@ ukr.net

** Associate Professor, Department of Public and Private Law, Kyiv V. I. Vernadsky Taurida National University. ORCID ID: https://orcid.org/oooo-0002-1285-966X. Email: valbortn83@meta.ua

*** Associate Professor, Department of Public and Private Law, Kyiv V. I. Vernadsky Taurida National University. ORCID ID: https://orcid.org/oooo-0002-2135-3820. Email: katbortn85@meta.ua

****Associate Professor, Department of Constitutional, Administrative and Financial Law, Faculty of Law, Leonid Yuzkov Khmelnytsky University of Management and Law. ORCID ID: https://orcid.org/oooo0003-3104-6071. Email: irynaa1975@gmail.com

***** Associate Professor, Department of General Law Disciplines, Faculty of Law, Dnipropetrovsk State University of Internal Affairs. ORCID ID: https://orcid.org/oooo-0003-3160-3333. Email: kafedra_ zpd675@ukr.net 


\section{Reformas Administrativas en Europa del Este: un Análisis Jurídico Comparado}

\section{Resumen}

El objetivo del artículo fue analizar la regulación legal de la reforma de descentralización en Europa del Este y su impacto en la tasa de empleo. En lo metodológico se utilizó análisis estadístico, método hipotéticodeductivo y correlación. Se encontró que la primera etapa de la reforma de la Nueva Administración Pública en Polonia, Ucrania, Rumania, la República Checa, Eslovenia, Letonia y Bulgaria comenzó en 1990, pero se puede llamar una etapa preparatoria informal. Se determina que el proceso de implementación de las reformas administrativas está influenciado por una serie de factores: históricos, económicos, geográficos. Se concluye que no existe una correlación positiva entre la efectividad de la administración pública y la efectividad del autogobierno local en todos los países estudiados. Está demostrado que la reforma de la descentralización tiene un impacto negativo en el empleo. Además, se encontró que Polonia es el país más estable entre los estudiados, con un alto nivel de eficiencia del autogobierno local. La correlación más negativa entre el índice de eficiencia del autogobierno local y el empleo, y la correlación más positiva entre los locales y la tasa de desempleo.

Palabras clave: administración pública; descentralización; nueva administración pública; empleo; desempleo.

\section{Introduction}

Administrative reforms are part of everyday life of modern countries, which are looking for new ways to manage the public sector under the influence of external and internal factors. Public sector reforms are actions of the government to reengineer the provision of public services in order to increase the efficiency and effectiveness of the civil service (Chand and Naidu, 2020).

The impetus for administrative reforms in public administration was fiscal stress caused by global changes in the economic system and the need to improve the work of the civil service (Aucoin, 1990). Governments have had to cut spending, staff, investment, and services, demand higher productivity and better performance from public authority. In order to obtain higher places for their countries in the world economic rankings, governments have been forced to rethink their role in governance and design country development strategies (Caiden, 2001). 


\section{Stanislav V. Zlyvko, Valerii A. Bortniak, Kateryna V. Bortniak, Iryna P. Storozhuk y Roman Z. Holobutovskyy

The issue of implementing administrative reforms is especially urgent in the new democracies of Central and Eastern Europe. The first wave of new public administration reform around the world began in the mid-1970's to increase government efficiency and effectiveness (Suzuki and Avellaneda, 2018). The second wave of the new administrative reform coincides with the beginning of European integration and accession to the EU.

The implementation of administrative reforms is a long-term process, which is due to the object of reform being unchanged throughout the period, while the ways of reform change according to the state of public administration.

\section{Literature Review}

Across Europe, there are three main paradigms of reform: the first paradigm concerns the introduction of Weberian style structures and processes, transforming tribal systems into modern administrations that are guided by the rule of law, operate transparently within a reasonable timeframe; the second reform paradigm, often referred to as New Public Administration, mainly concerns the introduction of a markettype mechanism; the third paradigm of reform combines elements of Weberianism with aspects of New Public Management (Hammerschmid et al., 2016).

The main administrative reforms were aimed at: relations between the central, regional, and local levels of government; organisation of public services; principles of financial management; development of state policy and evaluation of management results. The basis of administrative reform is the relationship between the state and society or between local selfgovernment and citizens (Nikos, 2001).

Decentralizationisanopen-ended conceptthatgoes beyondthetraditional categories of unitary and federal states (Harguindéguy et al., 2019). There are four main types of decentralisations: political, administrative, fiscal and market. Financial responsibility is a key component of decentralisation. Subnational governments and private organisations can effectively perform decentralised functions when they have the appropriate level of revenue that is collected locally or transferred from the national government - as well as the power to decide on expenditures (World Health Organization, n. d.).

The results of fiscal and administrative decentralisation are often analysed together with the consequences of the political and economic situation. The level of decentralisation reform has a positive and significant impact on the level of economic development of municipalities. The 
political subdivisions, which are the highest level in the structure of fiscal decentralisation, usually have a higher level of local employment. This suggests that fiscal decentralisation can be an important policy tool to stimulate local economic development and local employment (Bartlett et al., 2020). So, an effective policy to improve the labour market as part of decentralisation reform is possible only with the financial support of local governments (Churski, 2002). Levels of decentralisation can be seen as long-term effective responses to demands of investors and voters. Economic integration strengthens the requirements for fiscal decentralisation; however, economic integration is even more likely to have the opposite effect under certain conditions (Garrett and Rodden, 2000).

Fiscal decentralisation should improve the efficiency of local selfgovernments and stimulate production growth. However, empirical evidence is mixed. Fiscal decentralisation can affect economic growth in two ways: labour productivity and employment (Bartolini et al., 2019).

Employment is important for people's well-being, as it is crucial for financial well-being. There are many ways to increase employment rates: an effective unemployment benefit system, a social safety net in general, or a balanced labour market policy. Municipalities are more informed about local working conditions, the labour market and the unemployed who are looking for work. Decentralisation of public employment services would make them more effective in organising work and providing services (Nieminen, 2020).

Municipalities can organise and finance employment services more effectively, as local employment services have more information on employment issues and labour needs (Mergele and Weber, 2020). However, decentralisation is not an unequivocally effective tool. Boockmann et al. (2015) found that decentralisation had negative consequences for male employment and ineffective for women. The implementation of administrative reforms is critically dependent on a strong institutional foundation (Lapuente and Van de Walle, 2020).

Local branches of centralised public employment services are subject to the directives of the central institution. This allows monitoring their work more effectively, which facilitates the implementation of common standards and best practices. In a more decentralised environment, local branches of the public employment service are more flexible. They can develop independent strategies according to the specific conditions of their local labour market (Weber, 2016). 
Stanislav V. Zlyvko, Valerii A. Bortniak, Kateryna V. Bortniak, Iryna P. Storozhuk y Roman Z. Holobutovskyy

\section{Research Objectives}

The aim of the scientific article was to establish the legal regulation of the New Public Administration (decentralisation) reform in Eastern Europe and the impact of this reform of the New Public Administration on the employment rate.

Research objectives of the article:

1. Review the legal regulation of the New Public Administration (decentralisation) reform in the countries of Eastern Europe and the countries that last joined the EU.

2. Analyse statistical indicators that reflect the state of the New Public Administration (decentralisation) reform and employment.

3. Study the impact of the New Public Administration (decentralisation) reform and employment.

4. Provide a comparative legal description of the impact of the New Public Administration (decentralisation) reform and employment in the countries of Eastern Europe and the countries that have recently joined the EU.

\section{Materials and Methods of Research}

The main approach in the study of administrative reforms in Eastern Europe and the most recent EU member states was to establish the impact of NPA (decentralisation) reform on employment. This position is due to the construction of a logical chain consisting of the following components: administrative and fiscal decentralisation, policies aimed at economic growth of political subdivisions by attracting investors, expanding the private sector, and increasing jobs, which will reduce unemployment and improve the welfare of local people. The study was conducted based on statistics in Eastern Europe and the most recent EU member states. This approach was chosen to carry out a complete study of the impact of decentralisation on employment in countries that have actively pursued European integration with a view to joining the EU.

The study involved statistical analysis to compare data on the effectiveness of public and local government, employment and unemployment in Eastern Europe and the most recent EU member states.

The hypothetical-deductive method was conductive in determining the direction of the research, that is determining the impact of the NPA (decentralisation) reform on the employment rate in Eastern Europe and the most recent EU member states. 
The study also involved the method of correlation analysis to establish the correlation: between the local government efficiency index during 2005-2017 and the public administration efficiency index 2007-2016 in Poland, Ukraine, Slovenia, Bulgaria, the Czech Republic, Latvia, Romania; between the local government efficiency index during 2005-2017 and employment in relation to the population aged 15+ during 2005-2017 in the studied countries; between the local government efficiency index during 2005-2017 and the unemployment rate during 2005-2017 in the studied countries.

The research used the most significant studies that reflect the development of scientific thought in the field of administrative reforms for the period from 1990 to 2021. This period of analysis was chosen as the one that most clearly reflects the state of implementation of administrative reforms at the present stage.

The paper analyses the following indicators:

- Local Government Index 2005-2017 reflected by The World Bank.

- Government Efficiency Index 2007-2016 reflected by The World Bank.

- Employment to population ratio, 15+, total (\%) (modelled ILO estimate) for 2005-2017 reflected by The World Bank.

- Unemployment, total (\% of total labour force) (modelled ILO estimate) 2005-2017 reflected by The World Bank.

\section{Results}

Historically, the process of the New Public Administration (decentralisation) reform in Poland, Slovenia, Latvia, Bulgaria, Ukraine, the Czech Republic, and Romania has begun since 1990. There were no clearly defined reform strategies in any of the studied countries, so the first stages of NPA reform can be called a stage of preparation for the official start of this reform (Table 1). 
Stanislav V. Zlyvko, Valerii A. Bortniak, Kateryna V. Bortniak, Iryna P. Storozhuk y Roman Z. Holobutovskyy

820 Administrative reforms in Eastern Europe: A comparative legal analysis

Table 1. Legal regulation of the New Public Administration (decentralization) reform since 1990

\begin{tabular}{|c|c|c|}
\hline Countries & $\begin{array}{l}\text { The period of the New } \\
\text { Public Administration } \\
\text { (decentralisation) reform }\end{array}$ & Legal regulation \\
\hline Poland & $\begin{array}{l}\text { First stage - 1990-1999 } \\
\text { Second stage - 1999+ }\end{array}$ & $\begin{array}{l}\text { Territorial Self-Government Act } \\
\text { (1990), County Self-Government } \\
\text { Act (1998), Voivodeship } \\
\text { Self-Government Act (1998), } \\
\text { Voivodeship Government } \\
\text { Administration Act (1998). }\end{array}$ \\
\hline Slovenia & $\begin{array}{l}\text { First stage }-1991-1997 \\
\text { Second stage }-1997-2010 \\
\text { Third stage - 2010+ }\end{array}$ & $\begin{array}{l}\text { Strategy for EU Accession } \\
\text { (1997-1999), Strategy on } \\
\text { Further Development of the } \\
\text { Public Sector (2003-2005), } \\
\text { Slovenia's Development Strategy } \\
\text { (2005-2013) the Exit Strategy } \\
\text { (2010-2013) }\end{array}$ \\
\hline Latvia & $\begin{array}{l}\text { First stage }-1990-1998 \\
\text { Second stage }-1998-2009 \\
\text { Third stage }-2009+\end{array}$ & $\begin{array}{c}\text { Law on Administrative Territorial } \\
\text { Reform, (1998) } \\
\text { The Optimisation Plan, (2009) }\end{array}$ \\
\hline Bulgaria & $\begin{array}{c}\text { First stage }-1991-2000 \\
\text { Second stage }-2000-2006 \\
\text { Third stage }-2006+\end{array}$ & $\begin{array}{l}\text { Administration Act (1991), } \\
\text { Strategy for Decentralization } \\
\text { (2016). }\end{array}$ \\
\hline Ukraine & $\begin{array}{l}\text { First stage }-1991-2014 \\
\text { Second stage }-2014-2019 \\
\text { Third stage - 2020-2021 }\end{array}$ & $\begin{array}{l}\text { The Concept of Reforming Local } \\
\text { Self-Government and Territorial } \\
\text { Organisation of Power (2014), the } \\
\text { Law "On the Principles of State } \\
\text { Regional Policy",(2015), the Law } \\
\text { "On Civil Service" (2015), the Law } \\
\text { "On Cooperation of Territorial } \\
\text { Communities" (2020) }\end{array}$ \\
\hline $\begin{array}{c}\text { Czech } \\
\text { Republic }\end{array}$ & $\begin{array}{l}\text { First stage }-1991-2006 \\
\text { Second stage }-2007-2013 \\
\text { Third stage }-2014^{+}\end{array}$ & $\begin{array}{c}\text { Concept of Public Administration } \\
\text { Reform. } \\
\text { Strategy of Implementation } \\
\text { of Smart Administration in } \\
\text { the Period of } 2007-2015 \\
\text { (2007), Strategic Framework } \\
\text { of the Development of Public } \\
\text { Administration in the Czech } \\
\text { Republic for 2014 - 2020, (2014). }\end{array}$ \\
\hline Romania & $\begin{array}{l}\text { First stage }-1991-2001 \\
\text { Second stage }-2001-2006 \\
\text { Third stage }-2006+\end{array}$ & $\begin{array}{l}\text { Law of local public administration } \\
\text { (1991), Strategy for public } \\
\text { administration reform for } 2004- \\
2007 \text { (2004), Law No. 195/2006 } \\
\text { on decentralisation (2006). }\end{array}$ \\
\hline
\end{tabular}

Source: developed by the author. 
The process of public administration reform is long (Table 1) due to its variability to any changes taking place in the state. Accordingly, the global and national economic crises suspended the implementation of the NPU reform and partially returned to more centralised public administration (the global crisis of 2007-2008). The impetus for the NPA reform in the studied countries was European integration to join the EU (Bulgaria, Romania - 2007, Poland, Slovenia, Lithuania, the Czech Republic - 2004, Ukraine - in the process of European integration).

Local government indices are shown from o to 1 for 2005 to 2017 (Table 2). Poland has the highest local government index of for the studied years, which is stable at 0.99, Latvia, which is 0.99 during 2005-2015, Slovenia's index during the studied years was not lower than 0.98 .

Table 2. Local Government Index.

\begin{tabular}{|c|c|c|c|c|c|c|c|}
\hline & 2005 & 2007 & 2009 & 2011 & 2013 & 2015 & 2017 \\
\hline Poland & 0.99 & 0.99 & 0.99 & 0.99 & 0.99 & 0.99 & 0.99 \\
\hline Slovenia & 0.98 & 0.98 & 0.98 & 0.98 & 0.98 & 0.98 & 0.99 \\
\hline Latvia & 0.99 & 0.99 & 0.99 & 0.99 & 0.99 & 0.99 & 0.98 \\
\hline Bulgaria & 0.92 & 0.82 & 0.82 & 0.93 & 0.97 & 0.96 & 0.96 \\
\hline Ukraine & 0.92 & 0.95 & 0.84 & 0.84 & 0.95 & 0.95 & 0.96 \\
\hline Czech Republic & 0.93 & 0.93 & 0.93 & 0.93 & 0.90 & 0.90 & 0.90 \\
\hline Romania & 0.76 & 0.76 & 0.76 & 0.76 & 0.76 & 0.76 & 0.62 \\
\hline
\end{tabular}

Source: World Bank (2019a).

The highest government efficiency index from 2007 to 2016 (Table 3) was 3.84 recorded in Slovenia in 2009, the lowest government efficiency index was 2.59recorded in Ukraine in 2011.

Table 3. Government Efficiency, Index.

\begin{tabular}{|c|c|c|c|c|c|c|}
\hline & 2007 & 2009 & 2011 & 2013 & 2015 & 2016 \\
\hline Poland & 3.15 & 2.71 & 3.15 & 3.11 & 3.01 & 3.20 \\
\hline Slovenia & 3.53 & 3.84 & 3.65 & 3.11 & 2.74 & 2.95 \\
\hline Latvia & 3.60 & 3.39 & 3.07 & 3.40 & 3.37 & 3.46 \\
\hline
\end{tabular}


Stanislav V. Zlyvko, Valerii A. Bortniak, Kateryna V. Bortniak, Iryna P. Storozhuk y Roman Z. Holobutovskyy

Administrative reforms in Eastern Europe: A comparative legal analysis

\begin{tabular}{|c|c|c|c|c|c|c|}
\hline Bulgaria & 2.71 & 2.96 & 3.03 & 3.08 & 2.84 & 2.98 \\
\hline Ukraine & 2.75 & 3 & 2.59 & 2.68 & 2.68 & 2.87 \\
\hline Czech Republic & 3.20 & 3.03 & 3.18 & 3.03 & 3.45 & 3.68 \\
\hline Romania & 2.81 & 3.11 & 2.83 & 2.75 & 3.15 & 3.22 \\
\hline
\end{tabular}

Source: World Bank (2019b).

In order to establish the correlation between the effectiveness of local government and the effectiveness of public administration, it is necessary to conduct a correlation analysis of the indicators of Tables 2 and 3. In carrying out the analysis, we use the formula:

$$
r=\frac{\sum\left(x_{2}-\bar{x}_{1}\right) \times\left(x_{2}-\bar{x}_{2}\right)}{\sqrt{\sum\left(x_{1}-\bar{x}_{2}\right)^{2}} \times \sqrt{\sum\left(x_{2}-\bar{x}_{2}\right)^{2}}}
$$

where x1 - local government efficiency index and x2 - public administration efficiency index, $\mathrm{r}$ - linear correlation coefficient.

The linear correlation between the local government efficiency index and the public administration efficiency index in the studied countries during 2007-2017 (including the local government efficiency index in 2017 and the public administration efficiency index in 2016) was the following: Poland - -1.34, Slovenia - - 0.39, Latvia - -0.22, Bulgaria - 0.54, Ukraine - -0.14, the Czech Republic - -0.53, Romania - -0.58.

Thus, a negative correlation was established between the local government efficiency index and the public administration efficiency index, except for Bulgaria, where the linear correlation index is 0.54, which indicates the average level of correlation between the studied indicators.

The correlation between the local government efficiency index and the public administration efficiency index of the studied countries in 2007 is 0.699, which indicates a high level of correlation of indicators, and in 2015 this linear correlation index of these indicators is -0.274. Employment during 2005-2017 in the studied countries fluctuated slightly between 45.3\%-61.67\%. The lowest employment rate (45.3\%) was recorded in Bulgaria in 2005, and the highest (61.67\%) - in Ukraine in 2013 (Table 4). 
Table 4. Employment to population ratio, 15+, total (\%) (modelled ILO estimate).

\begin{tabular}{|c|c|c|c|c|c|c|c|}
\hline & 2005 & 2007 & 2009 & 2011 & 2013 & 2015 & 2017 \\
\hline Poland & 45.31 & 48.84 & 50.74 & 50.66 & 50.6 & 52.37 & 54.27 \\
\hline Slovenia & 55.36 & 56.89 & 55.95 & 53.33 & 51.66 & 52.27 & 54.68 \\
\hline Latvia & 51.52 & 56.56 & 49.57 & 49.11 & 52.31 & 54.13 & 55.88 \\
\hline Bulgaria & 45.3 & 50.09 & 50.62 & 46.62 & 46.89 & 49.22 & 52.04 \\
\hline Ukraine & 51.16 & 51.42 & 50.1 & 50.95 & 61.67 & 49.76 & 49.33 \\
\hline Czech Republic & 54.78 & 55.73 & 54.7 & 54.32 & 55.23 & 56.61 & 58.71 \\
\hline Romania & 49.63 & 50.72 & 50.04 & 50.24 & 50.61 & 50.74 & 52.29 \\
\hline
\end{tabular}

Source: World Bank (2021).

The impact of the NPA (decentralization) reform on employment can be determined by conducting a correlation analysis between the local government efficiency index and employment to the population aged 15+ during 2005-2017. The linear correlation index between these indicators in the studied countries is: Poland $-\mathbf{- 2 . 7 2}$, Slovenia - 0.084, Latvia -0.475, Bulgaria - -0.301, Ukraine - 0.244, Czech Republic - -0.692, Romania - -0.877.

Thus, the negative correlation between the local government efficiency index and employment is recorded in Poland, where the most stable local government efficiency index is established. The greatest correlation between these indicators of the studied countries is established in Ukraine, but the correlation coefficient indicates a low level of interdependence. It should be noted that Ukraine is not a EU member, decentralisation reform was launched in 2014.

The general correlation index between the local government efficiency index and employment in the studied countries in 2005 was 0.094, and in $2017-0.135$, which indicates a low level of interdependence.

The lowest unemployment rates in the surveyed countries during 20072017 were observed in Slovenia, Latvia, Ukraine in 2007, Poland, Bulgaria, the Czech Republic, and Romania in 2017 (Table 5). 
Stanislav V. Zlyvko, Valerii A. Bortniak, Kateryna V. Bortniak, Iryna P. Storozhuk y Roman Z. Holobutovskyy

Table 5. Unemployment, total (\% of total labour force) (modelled ILO estimate).

\begin{tabular}{|c|c|c|c|c|c|c|c|}
\hline & 2005 & 2007 & 2009 & 2011 & 2013 & 2015 & 2017 \\
\hline Poland & 17.75 & 9.6 & 8.17 & 9.63 & 10.33 & 7.5 & 4.89 \\
\hline Slovenia & 6.51 & 4.82 & 5.86 & 8.17 & 10.1 & 8.96 & 6.56 \\
\hline Latvia & 10.03 & 6.05 & 17.52 & 16.21 & 11.87 & 9.87 & 8.72 \\
\hline Bulgaria & 10.08 & 6.88 & 6.82 & 11.26 & 12.94 & 9.14 & 6.16 \\
\hline Ukraine & 7.18 & 6.35 & 8.84 & 7.85 & 7.17 & 9.14 & 9.51 \\
\hline Czech Republic & 7.93 & 5.32 & 6.66 & 6.71 & 6.95 & 5.05 & 2.89 \\
\hline Romania & 7.17 & 6.41 & 6.86 & 7.18 & 7.1 & 6.81 & 4.93 \\
\hline
\end{tabular}

Source: World Bank (2021).

By conducting a correlation analysis between the local government efficiency index and the number of unemployed (in\%) during 2005-2017, a linear correlation index was established between these indicators in the studied countries, which is: Poland -2.404 , Slovenia - -0.171, Latvia 0.295, Bulgaria - 0.546, Ukraine - -0.092, the Czech Republic - 0.544, Romania - -0.918.

The highest interdependence between the local government efficiency index and the number of unemployed (in\%) is found in Poland, the medium level of interdependence is recorded in the Czech Republic and Bulgaria, the lowest level - in Latvia. Negative interdependence was established in Slovenia and Ukraine. The general correlation index between the local government efficiency index and the number of unemployed (in\%) in the studied countries in 2005 was 0.421 , and in $2017-0.360$, which indicates a low level of interdependence.

\section{Discussion}

Over the past few decades, many unitary countries have sought decentralisation as a means of finding more efficient and optimal governance. Other countries were dissatisfied with the results of previous governance and centralised policies. Socio-economic problems have become more acute, causing the need to address them through poverty reduction, improving efficiency of the public sector and governance, greater macroeconomic stability, and fiscal sustainability (Martinez-Vazquez et al., 2016). 
Rethinking the results of centralised public administration and the tools for its implementation marked the launch of the third wave of administrative reforms - the New Public Administration, which was designed to expand the powers of local self-government with the possibility of self-financing. The central subjects of the New Public Administration reform are citizens who previously held a passive position in governance, and are now considered full social actors, which are the centre of the administrative reform policy (Nikos, 2001).

Decentralisation improves resource allocation, accountability, and cost recovery, while subnational governments are assumed to have better information than the central government on the problems and needs of the local population. It is also believed that the population is more aware of the actions of subnational governments than the central government. However, subnational governments do not automatically receive additional information about the local population, unlike the central government (Azfar et al., 2004). It is established that the interdependence between the efficiency of state power and the efficiency of local self-government is negative in the studied countries, except Bulgaria. Therefore, it is erroneous to claim that NPA (decentralisation) clearly has a positive effect on the effectiveness of public administration and local self-government.

Thus, we fully agree with the statements that: fiscal and administrative decentralisation improve perceptions of government performance; federalism is perceived negatively; the overall result of decentralisation is ambiguous; decentralisation affects the service sector more favourably than others; large companies perceive decentralisation less favourably than other companies; the effect of the same form of decentralisation differs within all public spheres; the form of decentralisation and its contextualisation in terms of defining the objectives of public activity, requires careful consideration and detailing (Goel et al., 2017).

Administrative and fiscal decentralisation are complementary reforms. Their effectiveness and efficiency cannot be unambiguous and the same for everyone. One of the important factors that must be taken into account when implementing decentralisation reform is geographical. Geography is an important factor that determines the reasonability of financial autonomy of local self-government. Mountain areas have limited financial resources and are more dependent on funding from the central government. The islands enjoy greater income autonomy than their continental counterparts (Abouelfarag and Qutb, 2020).

The explanation is that the island's economy is tourism-based, which serves as a local source of income growth through local fees and taxation. The most urbanised municipalities show a higher revenue autonomy and a lower dependence on public funding. Besides, education, unemployment and well-being of the population also depend on the finances of local self- 


\section{Stanislav V.Zlyvko, Valerii A. Bortniak, Kateryna V. Bortniak, Iryna P. Storozhuk y Roman Z. Holobutovskyy

government. Unemployment increases (hinders) local financial autonomy and makes local government less (more) dependent on the central government (Psycharis et al., 2015).

The factors are especially important for understanding the results of reforms, especially in comparison with other countries. These include: the administrative system and culture of the country or region, which is determined by its history (Kurilov, 2019); the initial status of the territory before the reform, especially the size, number of participating municipalities, type of amalgamation (merger against association) and reforms that have taken place in the past; reform process, implementation strategy; local government and the dynamics of consensus; political incentives and political leadership in the reform process; existing resources and the level of efficiency of individual local authorities (Ebinger et al, 2018).

Most local communities are currently unable to provide adequate services to the local population. It is established that in the context of local self-government reform the issue of employment and implementation of the state employment policy becomes the main task of the amalgamated territorial communities. At the same time, each amalgamated territorial community attaches great importance to the preservation and development of its human resources, which, in turn, effectively influences the state employment policy (Serohina, 2020).

It was found that decentralisation, which aimed at improving the efficiency of local self-government, which would increase the welfare of the population and best meet the needs of the community, had a negative impact on the employment rate. Poland has the highest local self-government efficiency index, while a negative correlation between the local self-government efficiency index and employment was revealed. In Ukraine, where the decentralisation reform started in 2014, the greatest interdependence between these indicators was found among the studied countries.

Evidence of the negative impact of decentralisation on employment is the greatest interdependence between the local government efficiency index and the number of unemployed (in \%) in Poland.

Therefore, we agree that decentralisation reform should not be seen as a tool to increase employment (Nieminen, 2020) and taken as an end in itself - it is implemented in order to better provide services, manage resources more efficiently or support other overall results. Internally, decentralisation increases the need for qualified staff in the civil service and in the field (World Bank Group, n. d.). Decentralisation reforms require a careful assessment of the causes of possible problems and economic opportunities in order to avoid unintended consequences (Mergele and Weber, 2020). 
Local self-governments need to develop strategies to attract investors in order to expand the private sector, which will increase the number of jobs and involve local people in work. As a result of consistent and effective local government policies, unemployment will decrease, the well-being of the population will improve and economic growth will be ensured (Nepram et al., 2021).

\section{Conclusion}

The study of administrative reforms in Eastern Europe is relevant, as in Eastern Europe for a long time there was centralised management. The wave of economic crisis and democratisation led to a wave of administrative reform aimed at decentralising governance by empowering local communities, as well as increasing the efficiency of local self-government. It was envisaged that such a policy would boost economic growth, redistribute funds effectively, improve the well-being of the local population and meet all the needs of the local community. However, the global economic crises have made their adjustments not in favour of administrative reforms. Public administration is a changing institution that responds to any changes taking place in the state, especially economic changes.

However, the global economic crises have made their adjustments not in favour of administrative reforms. Public administration is a changing institution that responds to any changes taking place in the state, especially economic changes. Accordingly, the implementation of administrative reforms is a rather long process, which includes the development of strategies, adoption of relevant legislation, adjustment and change of ways of reform in accordance with the needs of society. The study found that the current administrative reform in Eastern Europe is the New Public Administration reform. The study is based on the idea of the impact of decentralisation on employment, which is variable to the economic situation and governance policy and reflects the level of welfare of the population.

It was determined that the decentralisation reform did not have a positive effect on the public administration efficiency and the local government efficiency in the studied countries, except Bulgaria. There is a negative correlation between the local self-government efficiency and the employment rate, except in Slovenia and Ukraine, where there is a weak correlation. Regarding the impact of local governance on unemployment, the negative impact is recorded in Ukraine, Romania and Slovenia.

Evidence of the negative impact of decentralisation reform on employment is the analysis of data from Poland, which has a consistently high level of local government efficiency, the most negative correlation with employment and the largest correlation with unemployment during 
2005-2017, indicating ineffective policies of public and local government regarding the employment of citizens. At the same time, the study showed that in Ukraine, which has recently launched the decentralisation reform (since 2014), the policy of providing the population with jobs is more effective.

However, the results of administrative reforms are ambiguous, as their effectiveness is influenced by various factors, such as historical, geographical, economic.

The prospect of further research is to cover the organisational and economic aspects of the implementation of administrative reforms and their impact on sustainable development.

\section{Bibliographic References}

ABOUELFARAG, Hanan AbdelKhalik; QUTB, Rasha. 2020. Does government expenditure reduce unemployment in Egypt. In: Journal of Economics and Administrative Sciences (Ahead of print). Available online. In: https://doi.org/10.1108/JEAS-01-2020-0011. Date of consultation: 30/11/2020.

AUCOIN, Peter. 1990. "Administrative reform in public management: Paradigms, principles, paradoxes and pendulums" In: Governance: An International Journal of Policy and Administration. Vol. 3 No. 2, pp. 115137.

AZFAR, Omar; KAHKONEN, Satu; LANYI, Anthony; MEAGHER, Patrick; RUTHERFORD, Diana. 2004. "Devolution and Development", 1st Edition. Routledge, London, New York.

BARTLETT, William; ĐULIĆ, Katarina; KMEZIC, Sanja. 2020. "The impact of fiscal decentralisation on local economic development in Serbia" In: Journal of Local Self-Government. Vol. 18, No. 1, pp. 143-163.

BARTOLINI, David; NINKA, Eniel; ANTOLIN, Raffaella. 2019. "Tax decentralization, labour productivity, and employment in OECD countries” In: Applied Economics. Vol. 51, No. 34, pp. 3710-3729.

BOOCKMANN, Bernhard;THOMSEN, Stephan L.; WALTER, Thomas; GOBEL, Christian; HUBER, Martin. 2015. "Should welfare administration be centralized or decentralized? Evidence from a policy experiment" In: German Economic Review. Vol. 16, No. 1, pp. 13-42.

CAIDEN, Gerald E. 2001. "Administrative reform" In: Public Administration and Public Policy. Vol. 94, pp. 681-693. 
CHAND, Anand; NAIDU, Suwastika. 2020. New public management model and performance appraisal system. In Ali Farazmand (ed.), "Global Encyclopedia of Public Administration, Public Policy, and Governance.” Springer, Cham.

CHURSKI, Pawel. 2002. "Unemployment and labour-market policy in the new Voivodeship system in Poland" In: European Planning Studies. Vol. 10, No. 6, pp. 745-763.

EBINGER, Falk; KUHLMANN, Sabine; BOGUMIL, Joerg. 2018. “Territorial reforms in Europe: effects on administrative performance and democratic participation” In: Local Government Studies. Vol. 45, No. 1, pp. 1-23.

GARRETT, Geoffrey; RODDEN, Jonathan. 2000. "Globalization and Decentralization". Paper presented at the Annual Meeting of the Midwest Political Science Association in Chicago, IL on April 27-30, 2000.

GOEL, Rajeev K.; MAZHAR, Unnad; NELSON, Michael A; RAM, Rati. 2017. "Different forms of decentralization and their impact on government performance: Micro-level evidence from 113 countries" In: Economic Modelling. Vol. 62, pp. 171-183.

HAMMERSCHMID, Gerhard; VAN DE WALE, Andrews; RHYS, Steven; BEZES, Philippe. 2016. "Introduction: Public Administration Reforms in Europe. Public Administration Reforms in Europe. The View from the Top.” Edward Elgar Publishing. Cheltenham, Northampton, UK.

HARGUINDÉGUY, Jean-Baptiste Paul; COLE, Alistair; PASQUIER, Romain. 2019. "The variety of decentralization indexes: A review of the literature" In: Regional \& Federal Studies. Vol. 31, No. 2, pp. 1-24.

KURILOV, Yuriy. 2019. "Administrative reform in Ukraine: from its origins to the future" In: Public Administration Aspects. Vol. 7, No. 9-10, pp. 6278 .

LAPUENTE, Victor; VAN DE WALLE, Steven. 2020. "The effects of new public management on the quality of public services" In: Governance. Vol. 33, No. 3, pp. 461-475.

MARTINEZ-VAZQUEZ, Jorge; LAGO-PEÑAS, Santiago; SACCHI, Agnese. 2016. "The impact of fiscal decentralization: a survey" In: Journal of Economic Surveys. Vol. 31, No. 4, pp. 1095-1129.

MERGELE, Lukas; WEBER, Michael 2020. "Public employment services under decentralization: Evidence from a natural experiment" In: Journal of Public Economics. Vol. 182, No. 2, pp. 104-113. 
Stanislav V. Zlyvko, Valerii A. Bortniak, Kateryna V. Bortniak, Iryna P. Storozhuk y Roman Z. Holobutovskyy

830 Administrative reforms in Eastern Europe: A comparative legal analysis

NEPRAM, Damodar; SINGH, Salam Prakash; JAMAN, Samsur; 2021. "The Effect of Government Expenditure on Unemployment in India: A State Level Analy" In: Journal of Asian Finance, Economics and Business. Vol. 8, No. 3, pp. 0763-0769.

NIEMINEN, Jeremias. 2020. "Decentralized employment services and active labor market policy: Evidence from Finnish municipal employment trials". Master's thesis. University of Turku. Turku, Finland.

NIKOS, Michalopoulos. 2001. "Trends of administrative reform in Europe: Towards administrative convergence?” In: International Public Management Review. Vol. 2, No. 2, pp. 39-53.

PSYCHARIS, Yannis; ZOI, Maria; ILIOPOULOU, Stavroula. 2015. "Decentralization and local government fiscal autonomy: evidence from the Greek municipalities" In: Environment and Planning C: Government and Policy. Vol. 34, No. 2, pp. 262-280.

SEROHINA, Natalia O. 2020. "Decentralization and its impact on effective employment” In: Ekonomika ta Derzava. Vol. 1, 2, No. 14, pp. 79-83.

SUZUKI, K., AVELlanEDA, C. N. 2018. "New Public Management and Municipal Performance: Do NPM Reforms Boost Performance?" Available online. In: https://scholarlypublications.universiteitleiden. nl/handle/1887/80372. Date of consultation: 30/06/2021. Date of consultation: $30 / 11 / 2020$.

WEBER, Michael. 2016. The Short-Run and Long-Run Effects of Decentralizing Public Employment Services. ifo Working Paper Series 209. Leibniz Institute for Economic Research at the University of Munich. Leibniz.

WORLD BANK/ 2019a. Local Government Index. Available online. In: https://govdata36o.worldbank.org/indicators/hc9f5a751?country= UKR\&indicator $=41980 \&$ countries $=B G R, R O U, C Z E, L V A, P O L, S V N \&$ viz=line_chart\&years=2005,2018. Date of consultation: 30/02/2021.

WORLD BANK. 2019b. Government Efficiency. Available online. In: https://tcdata36o.worldbank.org/indicators/h8125e315?country= ROU\&indicator $=40979 \& v i z=$ line_chart\&years $=2007,2016$. Date of consultation: 30/02/2021.

WORLD BANK. 2021. Employment to Population Ratio, 15+, total (\%) (Modeled ILO Estimate). Available online. In: https://data.worldbank.org/ indicator/SL.EMP.TOTL.SP.ZS?end=2020\&locations=RO\&start=2005 Date of consultation: 30/02/2021. 
WORLD BANK GROUP. (n. d.) Administrative Decentralization. Available online. URL: http://www1.worldbank.org/publicsector/ decentralization/admin.htm Date of consultation: 30/02/2021.

WORLD HEALTH ORGANIZATION. (n. d.). "Health Laws and Universal Health Coverage." Available online. In: https://www.who.int/healthlaws/topics/governance-decentralisation/en/\#: :text=There\%20 are\%2othree\%20major\%2oforms,levels\%20of\%20a\%20national\%20 government Date of consultation: 30/11/2020. 

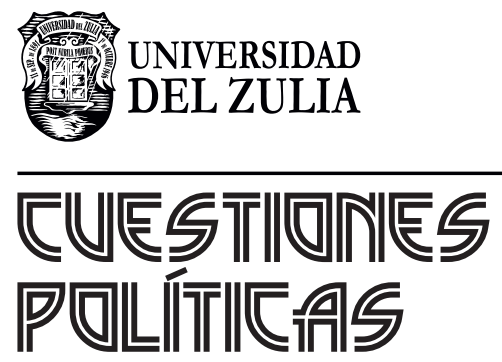

Vol.39 No 69

Esta revista fue editada en formato digital y publicada en julio de 2021, por el Fondo Editorial Serbiluz, Universidad del Zulia. Maracaibo-Venezuela 